Article

\title{
Multi-Port Zero-Current Switching Switched-Capacitor Converters for Battery Management Applications
}

\author{
Yat Chi Fong ${ }^{(D)}$, Ka Wai Eric Cheng* (D), S. Raghu Raman ${ }^{(D)}$ and Xiaolin Wang \\ Power Electronics Research Center, Department of Electrical Engineering, \\ The Hong Kong Polytechnic University, Hong Kong, China; yc-chi.fong@connect.polyu.hk (Y.C.F.); \\ raghu.sekhar@connect.polyu.hk (S.R.R.); xiaolinee.wang@connect.polyu.hk (X.W.) \\ * Correspondence: eeecheng@polyu.edu.hk; Tel.: +852-2766-6162
}

Received: 13 June 2018; Accepted: 21 July 2018; Published: 25 July 2018

check for updates

\begin{abstract}
A novel implementation of multi-port zero-current switching (ZCS) switched-capacitor (SC) converters for battery management applications is presented. In addition to the auto-balancing feature offered by the SC technique, the proposed SC converter permits individual control of the charging or discharging current of the series-connected energy storage elements, such as the battery or super-capacitor cells. This approach enables advanced state control and accelerates the equalizing process by coordinated operation with the battery management system (BMS) and an adjustable voltage source, which can be implemented by a DC-DC converter interfaced to the energy storage string. Different configurations, including the single-input multi-output (SIMO), multi-input single-output (MISO) SC converters, and the corresponding altered circuits for string-to-cells, cells-to-string, as well as cells-to-cells equalizers, are discussed with a circuit analysis and derivation of the associated mathematical representation. The simulation study and experimental results indicated a significant increase in the balancing speed with the presence of BMS and closed-loop control of cell currents.
\end{abstract}

Keywords: battery management system (BMS); switched-capacitor (SC); energy storage system; voltage balance

\section{Introduction}

Energy storage enables the functioning of electrical systems and modern utility configured with renewable energy sources. The electro-chemical battery and super-capacitor are two major technologies nowadays for energy storage systems (ESSs). In many applications of battery or super-capacitor based ESSs, like electric vehicles (EVs), stationary storage in backup systems, such as uninterruptible power supplies (UPSs) and online systems interfacing renewable generation or electrical grids, a huge number of energy storage cells are connected in series to achieve adequate voltage and power ratings. Due to the manufacturing tolerance and variations of the environmental conditions, the charge-discharge operation of the battery or super-capacitor as a whole string induces state-of-charge (SOC) inequality among individual cells. The imbalance in the SOC can push specific cells beyond the normal operating condition, degrade the lifespan of the energy storage devices, and, eventually, accelerate the failure of the system [1-4]. Therefore, charge equalization plays an important role in the management and maintenance of ESSs [2-5].

The techniques for charge equalization can be categorized into passive and active methods. Passive charge equalizers [6,7] employ passive shunt elements, like Zener diodes, resistors, or even the self-discharge leakage current, to attain cell balance. These passive methods are low cost and 
easy to implement, but the use of dissipative elements makes them inefficient and the balancing progress is usually limited by the thermal condition. In contrast, the active methods utilize power electronic converters to transfer charge and energy among energy storage cells. These include classical isolated topologies, like the fly-back or forward converters, and the non-isolated boost, buck-boost and switched-capacitor (SC) converters [1,6,8-12]. Along with the increasing penetration of battery and super-capacitor based ESSs, the development of advanced cell balancing technologies has become a significant research area. Numerous novel ideas, including coupled inductors [9,13-17], time-shared control [18-21], multistage structures [4,22] and resonant converters [23-25], have been reported for reducing the implementation cost and improving the performance of active equalizers for series-connected cells. Due to the simple working principle and ease of control with the configurable current setting, the fly-back topology remains successful in commercialized active battery equalizers. Still, the sizable footprint of the coupled inductors and the issues of additional loss and voltage spikes caused by the leakage inductance [14] increase the design difficulty and implementation cost of fly-back based active cell equalizers.

On the other hand, several multi-port SC converters [26-30] have been developed to realize auto-equalizers with an, essentially, zero voltage-gap. By utilizing capacitors as the major medium for charge transfer, it is possible to achieve compact and low cost implementation of the cell equalizer with the SC technique. The auto-balancing feature allows open-loop operation, with simple complementary gating signals for the active switches in the SC equalizer. This principally enables the possibility of an autonomous onboard equalizer without any complicated voltage sensing circuits. However, this feature can be a double-edged sword because the magnitude of the balancing current is determined by the voltage differences, aka voltage-gaps, among the cells. For the majority of electro-chemical systems, the typical voltage variations over the whole range are bound to be less than one-third of the rated voltage, and the exiguous voltage differences of the unequal cells would limit the speed performance of SC-based equalizers. Furthermore, this confines the applications of SC equalizers to simple voltage balancing. Without an interface and collaboration with the control from the battery management system (BMS), it is difficult to achieve advanced state control accounting for the thermal [31], and position [32] and dynamic [22,33] parameters of specific cells in the string; especially, for the applications of second-life batteries and hybrid energy storage packs [11,34,35].

The Single-Input Multi-Output (SIMO) and Multi-Input Single-Output (MISO) configurations have been employed to string-to-cells, cells-to-string, source-to-cells, and cells-to-load equalizers $[8,10,22,33,36]$. By adopting these configurations, it is possible to actively control the balancing currents disregarding the cell voltages. Instead of the voltage-gaps among the cells, the cell currents in the SIMO and MISO SC converters are determined by the voltage difference between the cells and the source, as well as the equivalent resistances of the SC units. Therefore, the balancing current magnitude can be controlled by adjusting the resistances with discrete or pulse-dropping gating control [37] or tuning the source voltage. In this paper, the working principle of the SIMO and MISO SC converters is explained with an overview of the circuit topologies, followed by the modeling and mathematical analysis on the SC equivalent resistance and balancing current. The source-to-cells and cells-to-load configurations can be altered into string-to-cells, cells-to-string, and cells-to-cells equalizers with a non-isolated DC-DC converter. Control and design consideration for the altered implementations also discussed.

\section{Overview of the SIMO and MISO SC Converters}

The SIMO and MISO configurations of the zero-current switching (ZCS) SC converter are illustrated in Figure 1a,b, respectively. An $n$ cells source-to-cells SC charger consists of $n$ SC units and an active switch, $T_{0}$, at the low side of the source. Likewise, an $n$ cells cells-to-load converter consists of $n$ SC units and an active switch at the high side of the load. An SC unit is constituted by a capacitor, an active switch, three diodes, and a resonant inductor. The switches, $T_{0}$ and $T_{1}$, operate in a complementary manner. For the SIMO configuration, the switched-capacitors 
are charged by the input voltage source when $T_{0}$ is conducting; discharge to charge the specific battery or super-capacitor cell when the corresponding $T_{1}$ is conducting; and vice versa for the MISO configuration. By inserting a resonant inductor in series with the switched-capacitor, zero-current switching is achieved. This dramatically reduces the equivalent resistance of the SC unit that improves the energy efficiency and current capability of the converter. The maximum voltage stresses of the diodes and active switches would be approximately the same voltage level as the total voltage of the energy storage string. Since all SC units share the same charging/discharging path through $T_{0}$, the current rating of $T_{0}$ would be about $n$ times of $T_{1}$.

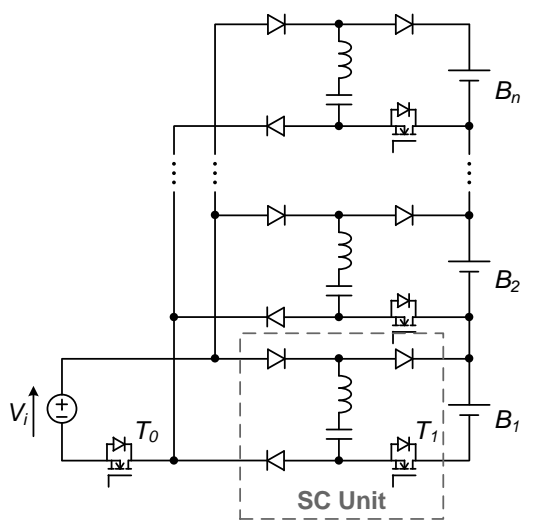

(a)

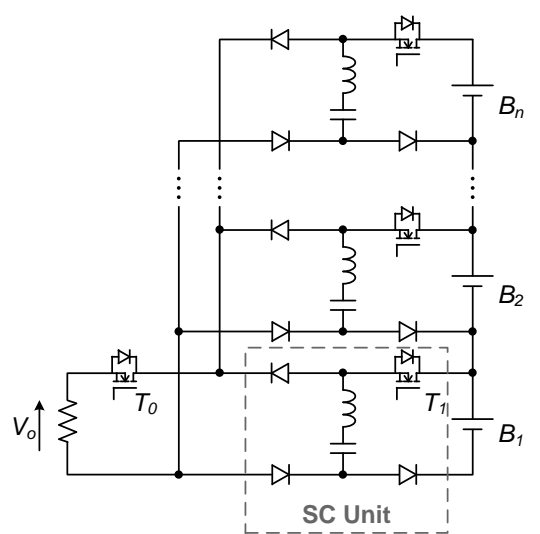

(b)

Figure 1. Generalized topology of the multi-port switched-capacitor (SC) converter; (a) Single-Input Multi-Output (SIMO) configuration; (b) Multi-Input Single-Output (MISO) configuration.

To realize individual charge control of the series-connected cells, the gating signals of the corresponding $T_{1}$ is enabled or disabled with discrete logic or pulse-width modulation (PWM) signal. This topology is beneficial from the small number of active components, for $n$ series cells, the number of metal-oxide-semiconductor field-effect transistors (MOSFETs) would be only $n+1$. However, the topology is only capable of handling unidirectional current. The proposed SIMO SC converter allows only charging current to the cells; whereas the MISO SC converter permits only discharging current from the cells.

\section{SC Modeling and Analysis}

\subsection{Equivalent Models of the SIMO and MISO SC Converters}

The voltage conversion ratio of SC converter is determined by the circuit topology. In the proposed configuration, the ideal voltage conversion ratio of each SC unit at lossless condition is unity. Considering the lossy components, the current magnitude is determined by the equivalent resistance of the SC unit and the difference between the input and output voltages. The behavioral models [30] of the proposed SC converters can be described as Figure 2.

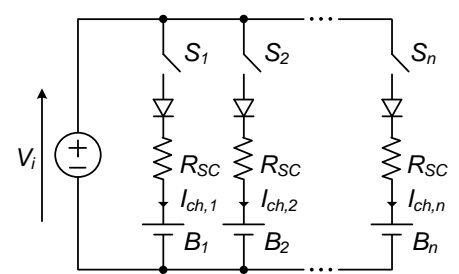

(a)

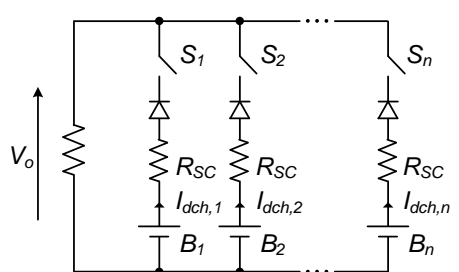

(b)

Figure 2. Behavioral model of the SC converter; (a) SIMO configuration; and (b) Multi-Input Single-Output (MISO) configuration. 
The average charging or discharging current for the $i$ th battery, $I_{c h, i}$ or $I_{d c h, i}$, can be described by the following functions:

$$
\begin{aligned}
I_{c h, i} & =\frac{V_{i}-3 V_{D}-V_{B i}}{R_{S C}} \cdot D_{i} \\
I_{d c h, i} & =\frac{V_{B i}-3 V_{D}-V_{o}}{R_{S C}} \cdot D_{i}
\end{aligned}
$$

where $V_{B i}$ is the voltage of the $i$ th cell, $V_{D}$ is the forward voltage drop of a diode, $D_{i}$ is the duty cycle of $S_{i}$, and the equivalent resistance, $R_{S C}$, of the $S C$ units is determined by the circuit parameters. Figure 3 illustrates the equivalent circuits of the SC unit during the conduction period of $T_{0}$ and $T_{1}$, respectively. In the SIMO configuration, the switched-capacitor is charged from the input voltage source through the resonant inductor, $L$, two diodes, and the switch, $T_{0}$, during the conduction period of $T_{0}$; and is discharged to the battery through the resonant inductor, a diode, and the switch, $T_{1}$, when $T_{1}$ is conducting. In contrast, the switched-capacitor in the MISO configuration is charged from the battery during the conduction period of $T_{1}$ and discharged to the load during the conduction period of $T_{0}$. Considering the lossy components, including the input source resistance, $R_{i}$, equivalent series resistance (ESR) of the capacitor and inductor, $R_{C}$ and $R_{L}$, diode resistance, $R_{D}$, the on-state resistances of the switches, $R_{T 0}$ and $R_{T 1}$, and the series resistance of the cell, $R_{B}$, in the charging and discharging paths of the switched-capacitor, $R_{0}=k R_{i}+R_{C}+R_{L}+2 R_{D}+k R_{T 0}$ and $R_{1}=R_{B}+$ $R_{C}+R_{L}+R_{D}+R_{T 1}$. Assuming that the battery voltages connecting to the activated SC units are close, the charging/discharging current of the SC units would be approximately the same. Therefore, the multiplication factor, $k$, for the on-state resistance, $R_{T 0}$, of $\mathrm{T}_{0}$ can be substituted by the number of activated SC units.

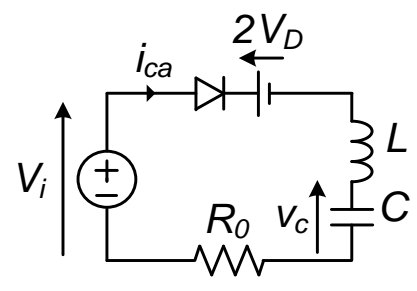

(a)

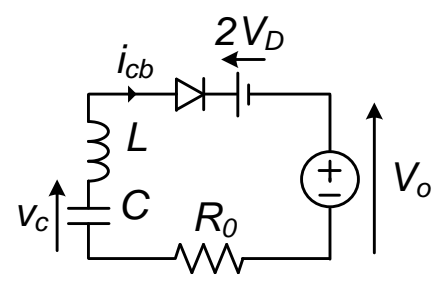

(c)

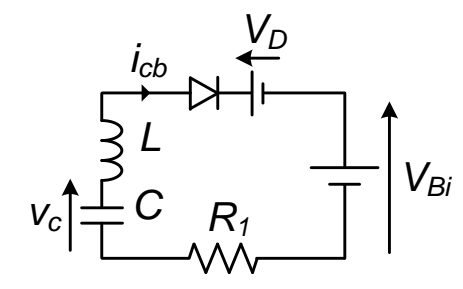

(b)

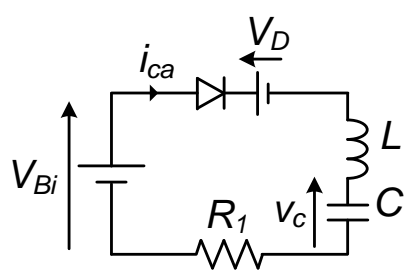

(d)

Figure 3. Equivalent circuits of the charging/discharging paths of the switched-capacitor; (a) conduction stage of $T_{0}$ in the SIMO configuration; (b) conduction stage of $T_{1}$ in the SIMO configuration; (c) conduction stage of $T_{0}$ in the MISO configuration; and (d) conduction stage of $T_{1}$ in the MISO configuration.

To attain ZCS operation, the parameters of the resistor-inductor-capacitor (RLC) damped circuit should be selected to ensure that the switched-capacitor is charged and discharged at an under-damped condition [38], i.e.,

$$
R_{0}<\sqrt{\frac{4 L}{C}} \text { and } R_{1}<\sqrt{\frac{4 L}{C}}
$$


By analyzing the under-damped waveforms of the capacitor voltage and current, as suggested in $[37,38], R_{S C}$ can be derived as Equation (4):

$$
R_{S C}=\frac{\tanh \beta_{0}+\tanh \beta_{1}}{2 f C}
$$

where $f$ is the switching frequency of the complementary switch pair, $T_{0}$ and $T_{1}$, also:

$$
\beta_{0}=\frac{\pi R_{0}}{2} \sqrt{\frac{C}{4 L-C R_{0}^{2}}} \text { and } \beta_{1}=\frac{\pi R_{1}}{2} \sqrt{\frac{C}{4 L-C R_{1}^{2}}}
$$

In addition to Equation (3), to assure the ZCS operation, the switching frequency, $f$, should be lower than the damped-resonant frequency that is a common guideline for ZCS [39,40], i.e.,

$$
f<\frac{1}{2 \pi} \sqrt{\frac{1}{L C}-\frac{R_{0}^{2}}{4 L^{2}}} \text { and } f<\frac{1}{2 \pi} \sqrt{\frac{1}{L C}-\frac{R_{1}^{2}}{4 L^{2}}}
$$

Given the condition that Equations (3) and (5) are fulfilled, according to Equation (4), the equivalent resistance, $R_{S C}$, of the $\mathrm{SC}$ unit is determined by the circuit resistance, inductance, capacitance, and the switching frequency, which are essentially constant. Based on Equations (1) and (2), the currents of the SIMO and MISO SC converters can be controlled by adjusting the input voltage, $V_{i}$, and load voltage, $V_{o}$, (or current), respectively, as well as tuning the duty cycle, $D$, of the pulse-dropping modulated signal of $T_{1}$.

\subsection{Efficiency Analysis of the SC Converters}

For the unity-mode SC converter, the charge is conserved, i.e., the amount of charges extracted from the input source will be the same of that outputted to the load. In other words, the efficiency is determined by the voltage drop of the SC unit. By comparing the input and output power, the power loss, $P_{L i}$, and efficiency, $\eta_{i}$, for the $i$ th SC unit can be expressed as Equations (6) and (7) respectively:

$$
\begin{gathered}
P_{L i}=\left\{\begin{array}{c}
I_{c h, i}\left(V_{i}-V_{B i}\right) \text { for SIMO configuration } \\
I_{d c h, i}\left(V_{B i}-V_{o}\right) \text { for MISO configuration }
\end{array}\right. \\
\eta_{i}=\left\{\begin{array}{l}
\frac{V_{B i}}{V_{i}} \text { for SIMO configuration } \\
\frac{V_{o}}{V_{B i}} \text { for MISO configuration }
\end{array}\right.
\end{gathered}
$$

By substituting Equations (1) and (2) into Equations (6) and (7), the power losses and efficiencies can also be expressed as follows:

$$
\begin{gathered}
P_{L i}=\left\{\begin{array}{l}
\frac{I_{c h, i}{ }^{2} R_{S C}}{D_{i}}+3 I_{c h, i} V_{D} \text { for SIMO configuration } \\
\frac{I_{d c h, i}{ }^{2} R_{S C}}{D_{i}}+3 I_{d c h, i} V_{D} \text { for MISO configuration }
\end{array}\right. \\
\eta_{i}=\left\{\begin{array}{l}
\frac{D_{i} V_{B i}}{D_{i}\left(V_{B i}+3 V_{D}\right)+I_{c h, i} R_{S C}} \text { for SIMO configuration } \\
\frac{D_{i}\left(V_{B i}-3 V_{D}\right)-I_{d c h, i} R_{S C}}{D_{i} V_{B i}} \text { for MISO configuration }
\end{array}\right.
\end{gathered}
$$


The overall efficiency, $\eta$, is simply represented by Equation (10):

$$
\eta=\left\{\begin{array}{l}
\frac{\sum_{i=1}^{n} I_{c h, i} \eta_{i}}{i} \text { for SIMO configuration } \\
\sum_{i=1}^{n} I_{c h, i} \\
\sum_{i=1}^{n} I_{d c h, i} \\
\frac{\sum_{i=1}^{n} \frac{I_{d c h, i}}{\eta_{i}}}{\eta_{i}} \text { for MISO configuration }
\end{array}\right.
$$

As suggested by Equation (8), the power loss of the equalizer increases dramatically with the charge or discharge current of the SC units; whereas the efficiency would also be affected by the cell voltage. In general, the proposed SC converter is more energy efficient at a higher cell voltage. Therefore, for ESS with a comparatively low cell voltage, the idea of double-tier or multi-tier structures [41] could be adopted, which improves not only the balancing speed, but also the conversion efficiency of the equalizer.

\section{Circuit Alteration with Non-Isolated DC-DC Converter}

A buck-boost converter with a particular voltage conversion ratio and potential level can adapt the SIMO and MISO SC converter to string-to-cells and cells-to-string equalizers, respectively. On the other hand, by inserting a boost converter, it is possible to combine the SIMO and MISO SC converters to form a cells-to-cells equalizer.

In the proposed multi-port SC converter, the no-load voltage conversion ratio is unity neglecting the voltage drops of the lossy components. Therefore, a DC-DC converter with a voltage conversion ratio of approximately $1 / n$ or $n$ is required to alter the SIMO or MISO SC converter into a string-to-cells or cells-to-string equalizer, respectively. To compensate the voltage drops caused by the diodes and the equivalent resistances of the SC units, the voltage conversion ratio (VCR) should be higher for the SIMO SC converter, whereas the VCR should be lower for the MISO counterpart. Considering the biasing direction of the diodes, the high side bus of the input source for the SIMO SC converter should be lower than that of the positive terminal of $B_{1}$; while the potential of the low side loading bus for the MISO SC converter should be lower than that of the negative terminal of $\mathrm{B}_{1}$. Based on the aforementioned criteria, the interfacing DC-DC converter between the SC converter and the energy storage string could be implemented by an inverting buck-boost converter (Figure 4a,b). Based on the voltage-second balancing of the inductor, $L_{b}$, the input or output voltage of the buck-boost converter can be controlled by varying the duty cycle, $D_{b}$, of the active switch, $Q_{1}$. Neglecting the lossy components, the relationship of the VCR under continuous current mode operation for the buck-boost converters in Figure $4 \mathrm{a}, \mathrm{b}$ can be expressed as Equations (11) and (12), respectively:

$$
\begin{gathered}
V_{i}=\frac{D_{b}}{1-D_{b}} \sum_{i=1}^{n} V_{B i} \\
V_{o}=\left(\frac{1}{D_{b}}-1\right) \sum_{i=1}^{n} V_{B i}
\end{gathered}
$$

On the other hand, the cells-to-cells equalization can be achieved by jointing the SIMO and MISO SC converters with a boost converter (Figure 4c). The two voltages across the boost converter under continuous current mode operation can be simply descripted as follows:

$$
V_{i}=\frac{V_{o}}{1-D_{b}}
$$

According to Equations (1), (2), and (11)-(13), the current of the multi-port SC converter would be increased with the duty cycle of $D_{b}$. However, as implied by Equation (7), this would reduce the 
balancing efficiency. Therefore, depending on the applications, the range of $D_{b}$ should be adjusted so that the balancing current fits the speed requirement.

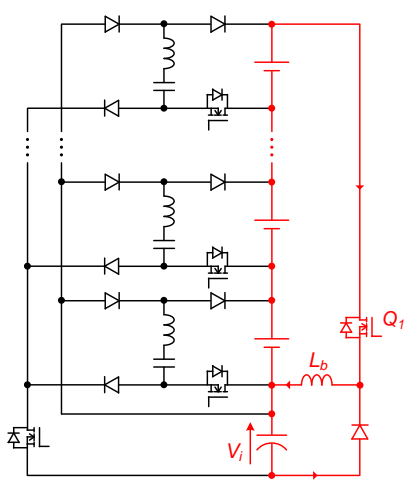

(a)

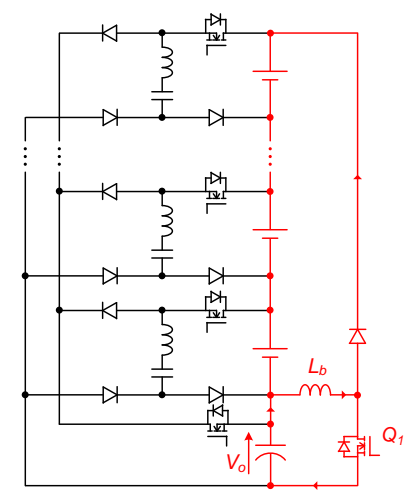

(b)

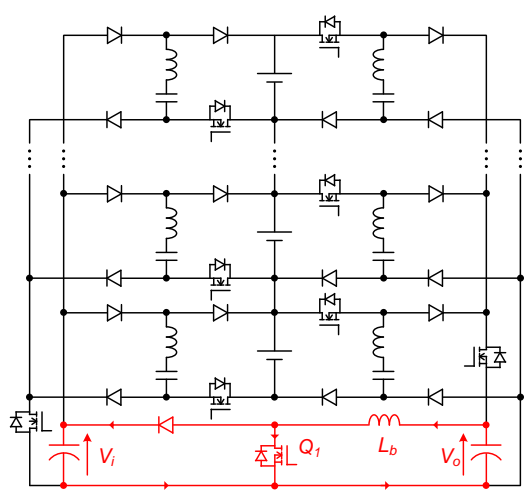

(c)

Figure 4. Circuit alteration of the multi-port SC converters; (a) string-to-cells implementation with the SIMO configuration and a step-down buck-boost converter; (b) cells-to-string implementation with the MISO configuration and a step-up buck-boost converter; and (c) cells-to-cells implementation with both the SIMO and MISO SC converters and a step-up boost converter.

\section{Verification}

To investigate the characteristics of the proposed multi-port SC converters, a simulation study on the models with different configurations and parameters listed in Table 1 was conducted. The switching frequency of the SC units was fixed at $30 \mathrm{kHz}$ and the damped resonant frequency, calculated from the RLC parameters, was about $32 \mathrm{kHz}$.

Table 1. Key parameters of the simulation model.

\begin{tabular}{cc}
\hline Parameters & Values \\
\hline Switching frequency, $f$ & $30 \mathrm{kHz}$ \\
Diode forward voltage drop, $V_{D}$ & $0.25 \mathrm{~V}$ \\
$C$ & $22 \mu \mathrm{F}$ \\
$L$ & $1 \mu \mathrm{H}$ \\
$R_{0}$ & $0.1+k \times 0.029 \Omega$ \\
$R_{1}$ & $0.109 \Omega$ \\
\hline
\end{tabular}

According to Equation (4), the equivalent resistance of an SC unit would be $0.647 \Omega$. By using the values listed in Table 1, the parametric analysis of the conversion efficiency at different cell voltages and currents are plotted in Figure 5. Referring to Equation (9), the multi-port SC converter would be more efficient at a higher cell voltage. For the SIMO configuration, the conversion efficiency would 
be about $70 \%$ at $1 \mathrm{~A}$ and $60 \%$ at $2 \mathrm{~A}$ for lithium cells, with the voltage ranging between $3 \mathrm{~V}$ to $4 \mathrm{~V}$; while the efficiency would increase to $>90 \%$ for the 6-cell modules rated at $22 \mathrm{~V}$. Although the MISO configuration allows safer operation by discharging specific cells that can effectively prevent cell over-charging, this operation would result in a reduced energy efficiency. Considering three batteries, having the voltage profile as suggested in [42] and the initial SOC of $70 \%, 75 \%$, and $80 \%$, undergo balancing charge to $90 \%$ at $0.15 \mathrm{C}$ and $0.3 \mathrm{C}$ string charging current (i.e., approximately $1 \mathrm{~h}$ and $30 \mathrm{~min}$ balancing duration, respectively). The balancing charge efficiencies [14] with traditional resistive balancing and the proposed SIMO SC equalizer employing a buck-boost stage with $80 \%$ efficiency were compared. By adopting the method suggested in [14] to calculate the balancing charge efficiency, which is a function of the Coulomb retention, the efficiency for traditional resistive balancing would be solely dependent on the initial SOC and final balanced SOC. Based on the parameters used, the resistive balancing efficiency would be $75 \%$ regardless of the cell voltage, capacity, or charging speed. On the other hand, the energy efficiency of the multi-port SC converter is dependent on the balancing current and module voltage, therefore, as illustrated in Figure 6, in fulfillment of attaining a balanced state at the same time of reaching $90 \%$ SOC, the balancing charge efficiency of the proposed SC equalizer would be varied with the module voltage, capacity, and charging speed.

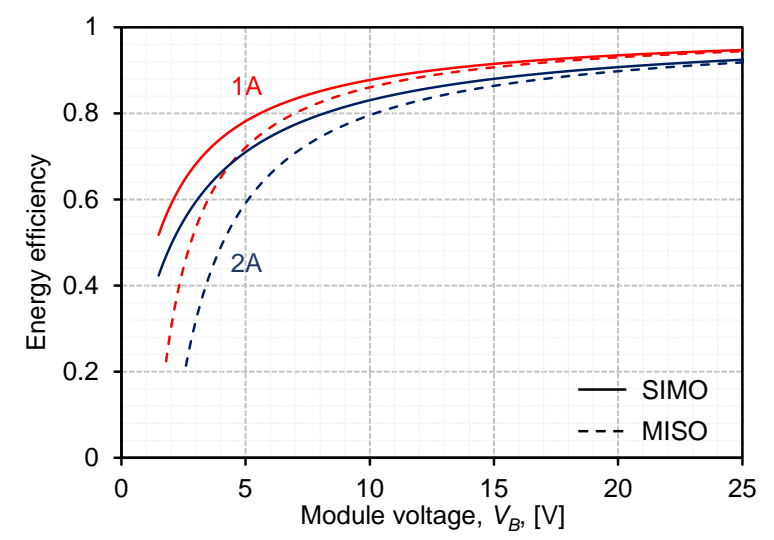

Figure 5. Efficiency of the SC converter model at different currents and voltages.

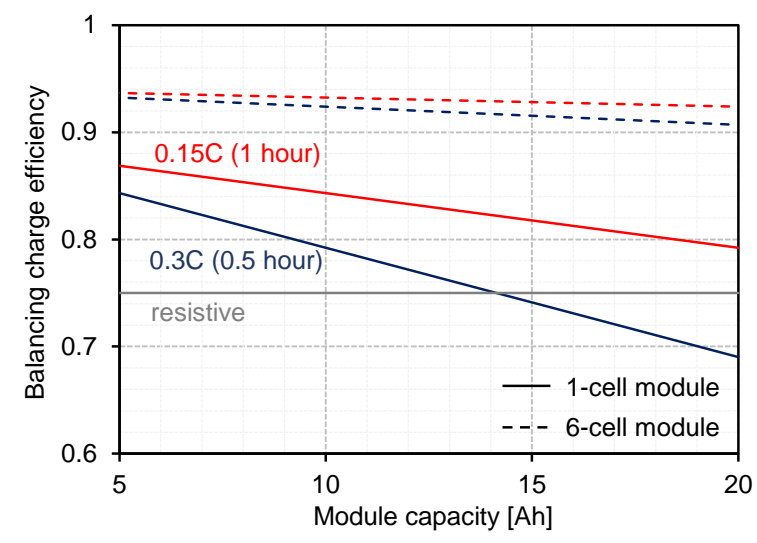

Figure 6. Balancing charge efficiency of the proposed SC equalizer at different currents and voltages.

The operation of the proposed multi-port SC converters was verified by conducting the simulation study on the models with four series-connected $350 \mathrm{~F}$ electric double-layer capacitors (EDLCs) employed as the energy storage string. The initial voltages of the EDLC cells, $B_{1}, B_{2}, B_{3}$, and $B_{4}$, were $2.0 \mathrm{~V}, 1.9 \mathrm{~V}, 1.5 \mathrm{~V}$, and $1.7 \mathrm{~V}$, respectively. In the first simulation setting, the $\mathrm{SC}$ converter with the aforementioned parameters, supplied by a voltage source, was implemented to charge the EDLC string. The maximum operating voltage of an ordinary EDLC cell is rated at $2.7 \mathrm{~V}$. The total forward voltage drop of the diodes in an SC unit would be about $0.75 \mathrm{~V}$. Adding a $0.05 \mathrm{~V}$ safety margin to 
the charging voltage, a voltage source of $3.4 \mathrm{~V}$ was used to charge the EDLC cells to the termination voltage of $2.65 \mathrm{~V}$. The gating signals of $T_{0}$ and $T_{1}$ were enabled throughout the charging period.

By substituting $k=4$, the average $R_{S C}$ of an SC unit would be about $0.85 \Omega$ according to Equation (4). Under open-loop control with the SIMO SC converter, the cell voltages were equally charged to about $2.65 \mathrm{~V}$ by the same $3.4 \mathrm{~V}$ voltage source. The termination voltage was determined by the source voltage and the diode voltage drop, whereas the charging currents were determined by the voltage difference between the EDLC cell and the termination voltage as well as the equivalent resistance, $R_{S C}$, of the SC unit. The balancing progress was $90 \%$ (i.e., the cell voltage difference attained $10 \%$ of the initial value) at about $494 \mathrm{~s}$ (Figure 7a). On the other hand, the MISO SC converter with the same parameters was simulated to discharge to a $0.75 \mathrm{~V}$ DC source under open-loop control (Figure $7 \mathrm{~b}$ ). This would result in termination cell discharge voltage of about $1.5 \mathrm{~V}$ taking the diode voltage drop into account. Since the initial voltage of $\mathrm{B}_{3}$ was $1.5 \mathrm{~V}$, leading to a zero discharge current, the average $R_{S C}$ was about $0.79 \Omega$ by substituting $k=3$. As shown in Figure $7 \mathrm{~b}$, the balancing duration for $90 \%$ progress was about $618 \mathrm{~s}$. The simulated initial total charging current for the SIMO and MISO SC converters were around 4.0 A and 1.4 A, respectively which conformed to the approximation of Equations (1) and (2). Also, the zoomed waveforms of the switched-capacitor voltage, $v_{\mathcal{C}}$, and current, $i_{c}$, in the SIMO SC converter were captured and are illustrated in Figure 8. The switched-capacitor voltage and current of the SC unit connect to the $B_{1}$ oscillates at the switching frequency of $30 \mathrm{kHz}$. The capacitor voltage and current, $v_{\mathcal{C}}$, swung between $3.19 \mathrm{~V}$ and $1.84 \mathrm{~V}$ at about $t=0.5 \mathrm{~s}$. Considering that, the maximum and minimum capacitor voltages were larger than $V_{i}-2 V_{D}$ and lower than $V_{B 1}+V_{D}$, respectively. The SC unit was operated at an under-damped condition. Besides, the capacitor current waveform indicates that ZCS was attained with the parameters listed in Table 1 and designed according to Equations (3) and (5).

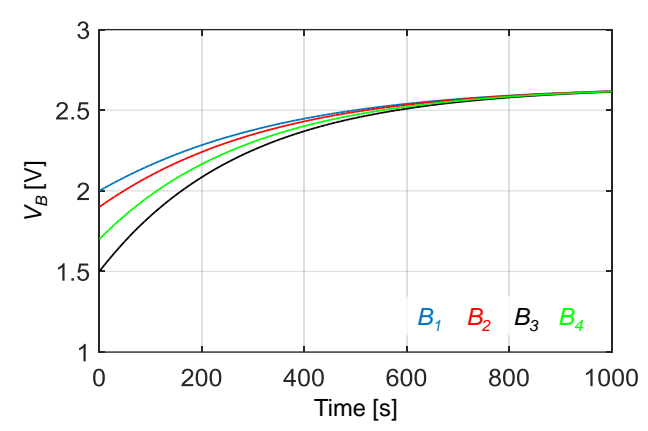

(a)

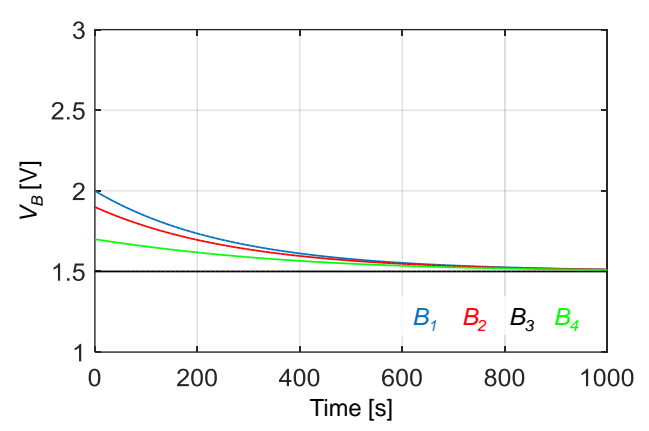

(b)

Figure 7. Electric double-layer capacitor (EDLC) cell voltage, charged by the open-loop multi-port SC converter; (a) the SIMO configuration with a $3.4 \mathrm{~V}$ voltage source; and (b) the MISO configuration with a $0.75 \mathrm{~V}$ voltage source.
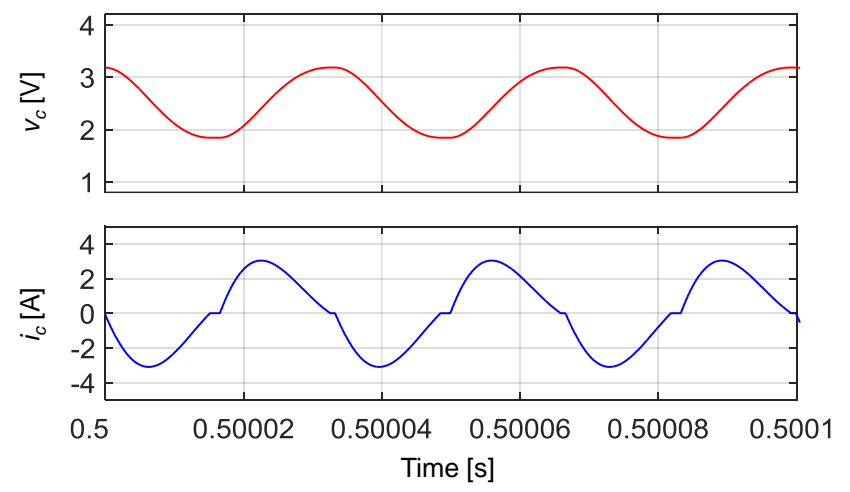

Figure 8. Zoomed waveforms of the switched-capacitor voltage and current at about $t=0.5$. 
To increase the speed of the equalizing charge of the series-connected cells, the multi-port SC converter can cooperate with the BMS to control the charging current of an individual cell. In the second simulation setting, the gating signals of $T_{1}$ in the same SIMO SC converter model were controlled by a simple logic Equation (14). The target of this closed-loop control was attaining equal cell voltages. Therefore, the cell voltages were sensed and fed-back to a central controller. The respective SC charging channels were activated when the corresponding cell voltages were higher than the average cell voltage and vice versa. The new charging voltages of the series-connected EDLC cells are depicted in Figure 9a.

$$
D_{i}=\left\{\begin{array}{c}
1 \text { for } V_{B i}<\frac{1}{n} \sum_{j=1}^{n} V_{B j} \text { and } V_{B i}<2.65 \\
0 \text { for } V_{B i} \geq \frac{1}{n} \sum_{j=1}^{n} V_{B j} \text { or } V_{B i} \geq 2.65
\end{array}\right.
$$

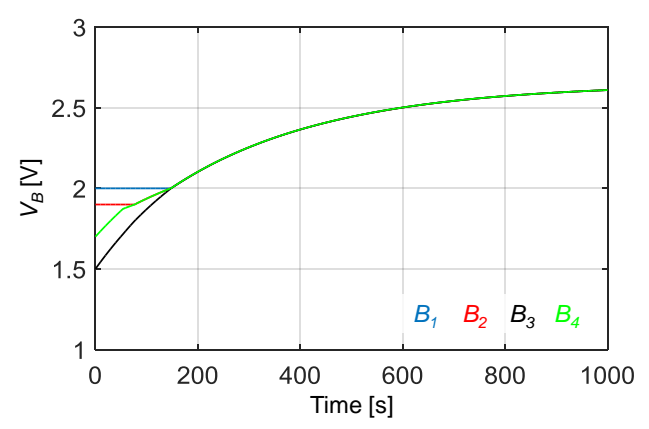

(a)

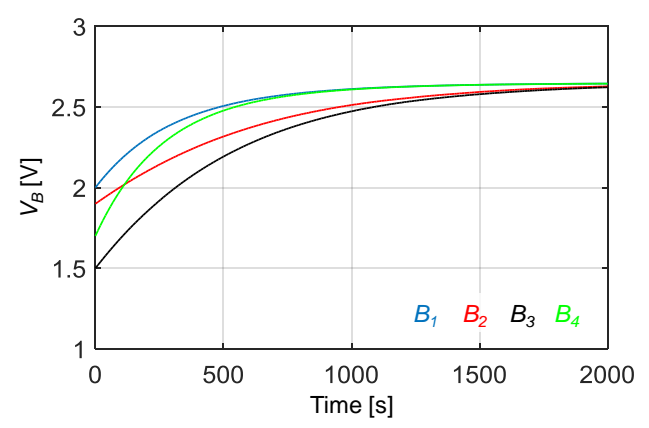

(c)

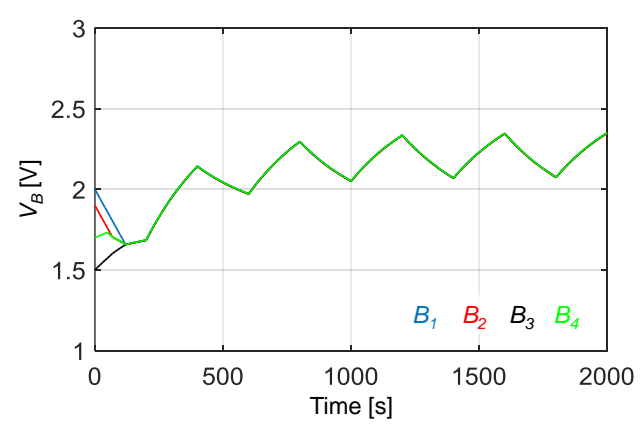

(b)

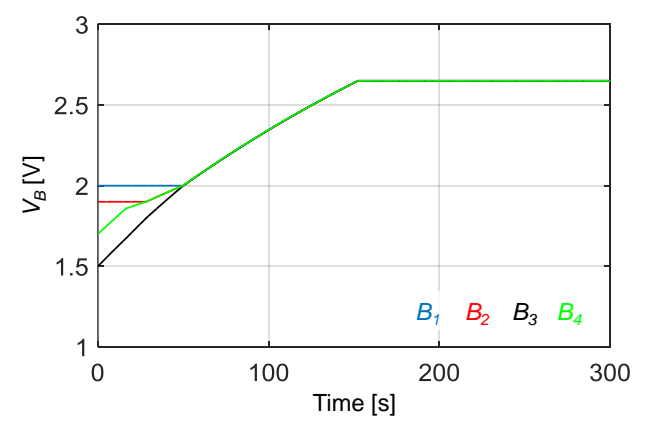

(d)

Figure 9. EDLC cell voltage, charged by the closed-loop SIMO SC converter; (a) with an input source voltage of $3.4 \mathrm{~V}$ and control logic in Equation (14); (b) with a dynamic string load; (c) with pulse-dropping control, $D_{1}=D_{4}=1$, and $D_{2}=D_{3}=0.5$; and $(\mathbf{d})$ with an input source voltage of $5 \mathrm{~V}$.

The cell voltages were compared with the average voltage of the string with a hysteresis band of $1 \mathrm{mV}$. By allowing the closed-loop control of the SC converter, the duration of attaining the $90 \%$ balancing progress was shortened to about $128 \mathrm{~s}$ in the closed-loop setting. Also, the same setting was simulated with a dynamic situation that 1 A current pulse of $200 \mathrm{~s}$ duration was applied at an interval of $400 \mathrm{~s}$ (Figure $9 \mathrm{~b}$ ). Under this setting, the EDLC cells attained the $90 \%$ balancing progress at about $107 \mathrm{~s}$; and, finally, converged to the equilibrium at around $2.22 \mathrm{~V}$, where the average charging current was $0.5 \mathrm{~A}$. This also confirmed the equivalent model described by Equation (1) with $R_{S C}=0.85 \Omega$. Moreover, the current magnitude can be adjusted by the duty cycle, $D_{i}$. For a simulated situation, the charging current of the center cells, $B_{2}$ and $B_{3}$, needed to be reduced due to the thermal condition, and the respective SC channels were activated by a $1 \mathrm{kHz}$ PWM signal with a duty cycle of 0.5 instead of constant high logic. With the same $3.4 \mathrm{~V} \mathrm{DC}$ source and termination voltage of $2.65 \mathrm{~V}$, the charging voltage curve under this condition is depicted in Figure 9c. With the reduced current control, $B_{2}$ and 
$B_{3}$ required about two times longer charging duration comparing to that of $B_{1}$ and $B_{4}$. As indicated in Equation (1), the charging current is dependent on the source voltage, $V_{i}$. By increasing the input voltage to $5 \mathrm{~V}$, the charging, as well as the balancing speed, dramatically increased. As depicted in Figure $9 \mathrm{~d}$, the duration of attaining $90 \%$ progress was about $44 \mathrm{~s}$ and settled at $2.65 \mathrm{~V}$ quickly.

The SIMO SC converter model was altered to a string-to-cell equalizer by inserting a buck-boost stage with an inductor, $L_{b}=220 \mu \mathrm{H}$, and switching frequency of $50 \mathrm{kHz}$. The EDLC string was charged by a constant current-constant voltage (CC-CV) charger with CC and CV values of $2 \mathrm{~A}$ and $10.6 \mathrm{~V}$, respectively. The cell voltages through the charging operation with 0.32 and 0.35 duty cycles for the switch, $Q_{1}$, are illustrated in Figure 10.

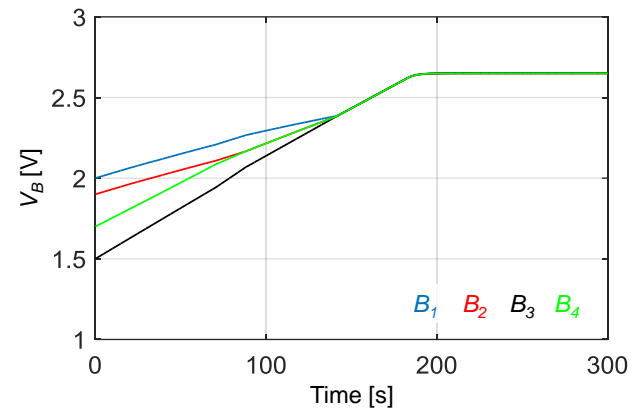

(a)

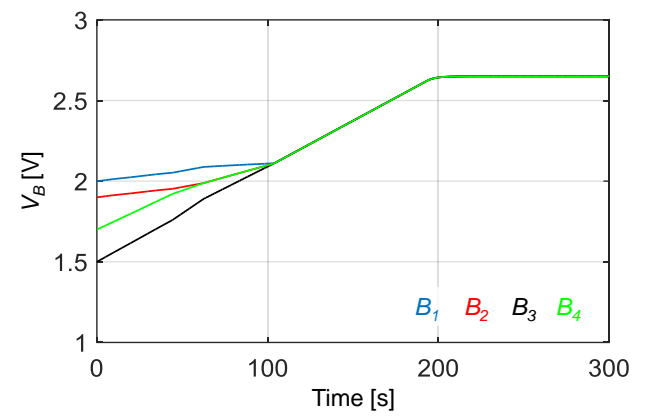

(b)

Figure 10. EDLC cell voltage, charged by the constant current-constant voltage (CC-CV) charger with the string-to-cell balancer altered from the SIMO SC converter; (a) with a 0.32 duty cycle for $Q_{1}$; and (b) with a 0.35 duty cycle for $Q_{1}$.

In the string-to-cell balancer, the input voltage for the SIMO SC converter was controlled by the duty cycle of the buck-boost stage. Hence, the equalizing current can be adjusted by varying the duty cycle of $Q_{1}$. As shown in Figure 10, with the remaining other parameters the same, the durations for attaining $90 \%$ of the balancing progress with 0.32 and 0.35 duty cycles were $129 \mathrm{~s}$ and $94 \mathrm{~s}$, respectively.

Furthermore, the operation of the cells-to-string and cells-to-cells configurations was compared and investigated with the corresponding altered circuit models. For the cells-to-string equalizer that was altered from the MISO SC converter, a very high voltage conversion ratio of the buck-boost stage was required. Even at $90 \%$ of the duty cycle, the equalizing speed was not fast enough to attain a balanced state before the EDLC cells were fully charged by the CC-CV source. In this case, the technique of the tapped inductor [43] was required to boost-up the voltage conversion ratio. Figure 11 illustrates the use of the tapped inductor in the altered MISO SC converter. In the simulation model, the tap position was at the center of $L_{b}$, resulting in a tap ratio of 1:1 and inductance of about $60 \mu \mathrm{H}$ for each side. The simulation results of the non-tapped model and the tapped inductor alternative are demonstrated in Figure 12. As a result of the increased voltage conversion ratio, the equalizing speed of the cells-to-string balancer with the tapped inductor was higher.

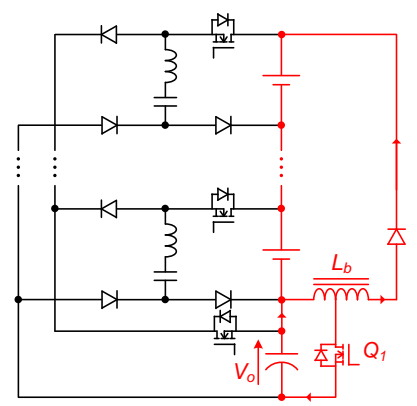

Figure 11. Use of a tapped inductor in the buck-boost stage to achieve a higher voltage conversion ratio. 


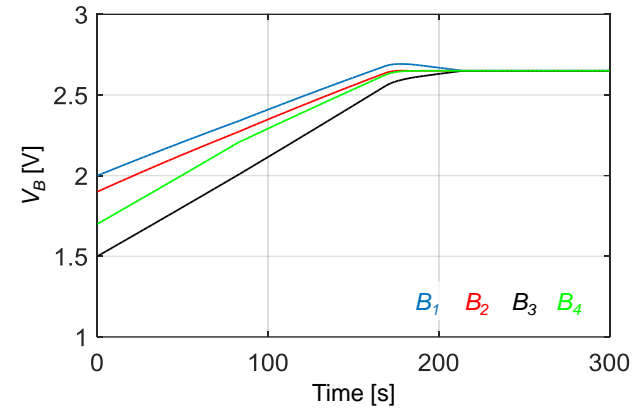

(a)

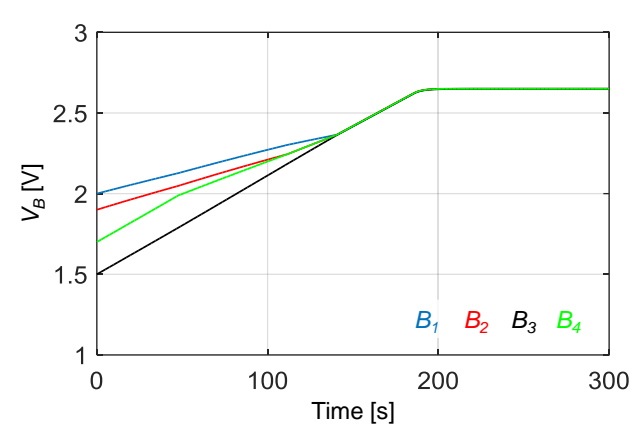

(b)

Figure 12. EDLC cell voltage, charged by the CC-CV charger with the cells-to-string balancer altered from the MISO SC converter; (a) with a non-tapped inductor and a 0.9 duty cycle for $Q_{1}$; and (b) with a tapped inductor.

For the cells-to-cells balancer, which consisted of the MISO and SIMO SC converters jointed by a boost converter with an inductor of $220 \mu \mathrm{H}$, the duty cycle of $Q_{1}$ was set to 0.8 to achieve $90 \%$ of the balancing duration of approximately $109 \mathrm{~s}$ (Figure 13).

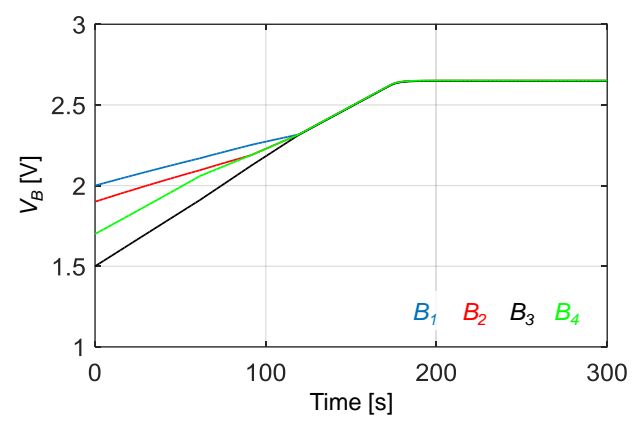

Figure 13. EDLC cell voltage, charged by the CC-CV charger with the cells-to-cells balancer.

By taking into consideration the implementation cost and performance of different equalization structures, the string-to-cells SC balancer would be more suitable for the configuration of four series EDLC cells. The operation of the proposed string-to-cells SC balancer was verified by experimental measurement of the balancer prototype with four series connected EDLC cells. Figure 14 shows the major components in the experimental setup; the key parameters are listed in Table 2.

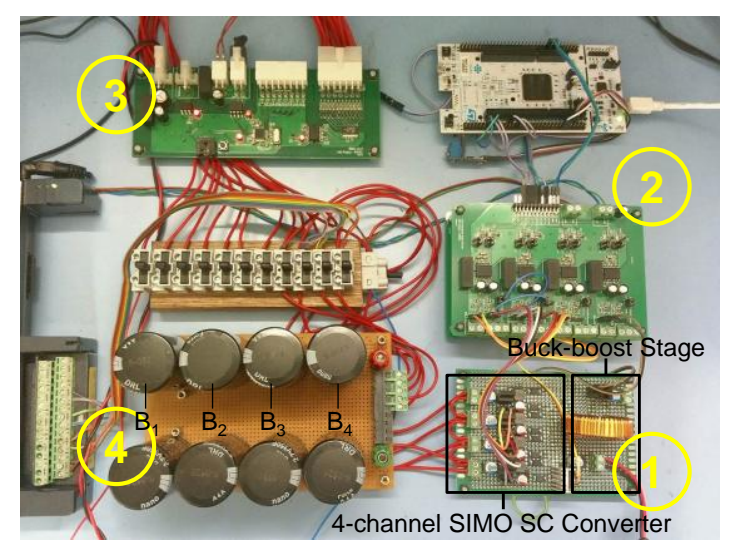

Figure 14. Major components in the experiment setup. (1) String-to-cells SC balancer prototype; (2) microcontroller and gating circuits; (3) LTC6803 based cell monitoring unit; and (4) series connected EDLC cells with fused terminals. 
Table 2. Key parameters of the experimental setup.

\begin{tabular}{cc}
\hline Parameters & Values \\
\hline Type of cells & $350 \mathrm{~F}$ EDLC \\
Number of cells, $n$ & 4 \\
Switching frequency of the SC converter, $f$ & $30 \mathrm{kHz}$ \\
Switching frequency of the buck-boost stage & $50 \mathrm{kHz}$ \\
Switches, $T, Q$ & TK30A06N1 n-MOSFETs \\
Diodes & SBRT10U50SP5-13 Schottky diodes \\
Switched-capacitors, $C$ & $22 \mu \mathrm{F}$ aluminum polymer capacitors \\
Resonant inductors, $L$ & $1 \mu \mathrm{H}$ SMD inductors \\
Power inductor, $L_{b}$ & $220 \mu \mathrm{H}$ through-hole inductor \\
Filter capacitors & $330 \mu \mathrm{F}$ aluminum polymer capacitors \\
\hline
\end{tabular}

Firstly, the EDLC was charged by a 4-channel SIMO SC converter with a $3.4 \mathrm{~V}$ input source voltage and open-loop setting. The switches, $T_{0}$ and $T_{1}$, were driven by a complementary gating signal at a constant switching frequency of $30 \mathrm{kHz}$; the initial voltages of the $350 \mathrm{~F}$ EDLC cells, $B_{1}, B_{2}, B_{3}$, and $B_{4}$ were set to approximately $2 \mathrm{~V}, 1.9 \mathrm{~V}, 1.5 \mathrm{~V}$, and $1.7 \mathrm{~V}$, respectively. The voltage across each EDLC cell was measured by a data logger at the rate of 10 samples per second for each channel. The measured cell voltages throughout the open-loop set-up are plotted in Figure 15a. Similar to the simulation results, auto-balancing was achieved by the multi-port SC converter with simple complementary gating signals. In the experimental setup, the time to attain $90 \%$ of the balancing progress was around $300 \mathrm{~s}$. To speed-up the balancing process, the cell voltages were fed-back to the microcontroller by a cell monitoring unit based on LTC6803 (Analog Devices, Norwood, MA, USA), which simulated the presence of the BMS; the gating signals of the output channels of the SC converter were controlled by the discrete function indicated in Equation (13) at an updating rate of $5 \mathrm{~Hz}$; the input source voltage was raised to $5 \mathrm{~V}$; considering the $40 \mathrm{~s}$ duration for attaining $90 \%$ of the balancing progress, the equalizing speed was sped up by more than seven times with the closed-loop setting cooperating with a BMS.

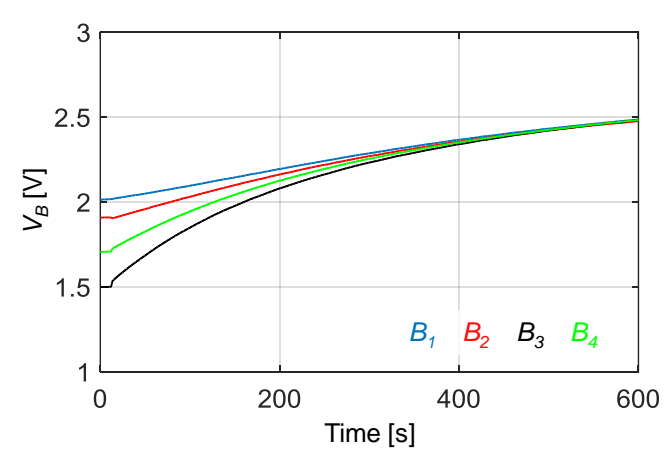

(a)

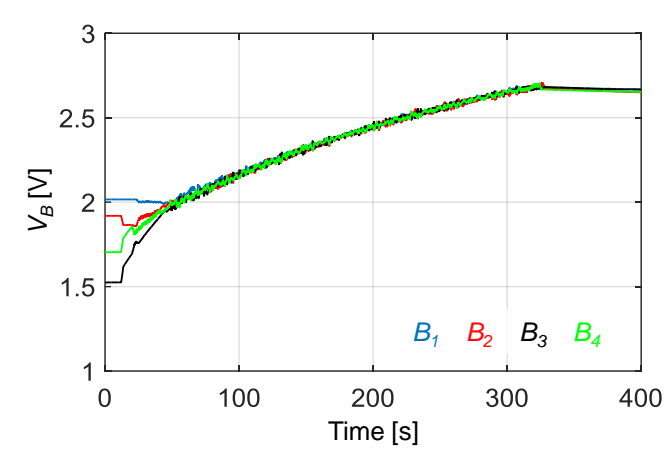

(b)

Figure 15. Measured EDLC cell voltage, charged by the open-loop SIMO SC converter. (a) With an input source voltage of $3.4 \mathrm{~V}$; and (b) with an input source voltage of $5 \mathrm{~V}$.

Similar to the simulated waveforms, the measured waveforms of the switched-capacitor (Figure 16) indicated that the SC converter operated at ZCS. With an input voltage of $3.4 \mathrm{~V}$ and an output voltage of about $2 \mathrm{~V}$, the capacitor voltage and current swung between $1.9 \mathrm{~V}$ and $3.1 \mathrm{~V}$ and $\pm 2.7 \mathrm{~A}$, respectively. The damped resonant frequency of the prototype with the same inductor-capacitor (LC) parameters was slightly higher than the $30 \mathrm{kHz}$ switching frequency. This coincided with the estimated value of about $32 \mathrm{kHz}$. When the input voltage was raised to $5 \mathrm{~V}$, the output current of the SC converter dramatically increased; which was reflected on the amplitude of 
the capacitor and inductor current. When the input voltage was $3.4 \mathrm{~V}$, the measured output current of the SC channel was approximately $0.86 \mathrm{~A}$; the current rose to about $3.08 \mathrm{~A}$ when the input voltage was increased to $5 \mathrm{~V}$. This observation could be fitted to the equivalent model in Equation (1) by substituting $R_{S C}=0.72 \Omega$ and a diode forward voltage drop of $V_{D}=0.26 \mathrm{~V}$. Also, the string-to-cells operating was implemented by an additional buck-boost stage. The EDLC string was charged by a CC-CV power source with maximum voltage and current settings of $10.6 \mathrm{~V}$ and $2 \mathrm{~A}$. By setting the duty cycle of $\mathrm{Q}_{1}$ to 0.35 , the output voltage of the buck-boost with $10.6 \mathrm{~V}$ input voltage was around $5 \mathrm{~V}$ at the continuous current mode. Due to the lossy components, including the diode forward voltage drop and parasitic resistances, the VCR was slightly lower than the ideal value calculated by Equation (11). The voltage and current waveforms of the power inductor, $L_{b}$, in the buck-boost stage during the output current of roughly $3.5 \mathrm{~A}$ are illustrated in Figure 17. The interaction between the switching components of the SC converter and buck-boost converter was essentially decoupled by the LC filter constituted by $L_{b}$ and the output filter capacitor. As shown in Figure 17, the interaction between the SC converter and DC-DC converter frequencies was insignificant in that the $30 \mathrm{kHz}$ SC switching component is hardly observed in the inductor waveforms. With the experimental parameters, the current ripple magnitude of the inductor was below $10 \%$. The cell voltages throughout the charging process were recorded. As depicted in Figure 18, the cell voltage reached $90 \%$ of the balancing progress at about $55 \mathrm{~s}$ and finally settled at around $2.6 \mathrm{~V}$. As the equalization speed was dependent on the input voltage of the SIMO SC converter, considering that the initial string voltage was about $7.5 \mathrm{~V}$ in this setting, the output voltage of the buck-boost stage varied from $3.5 \mathrm{~V}$ to $5 \mathrm{~V}$ during the charging process. As a result, the string-to-cells setting required a slightly longer equalization time compared to the set-up with the $5 \mathrm{~V}$ constant voltage source, as demonstrated in Figure 15b.

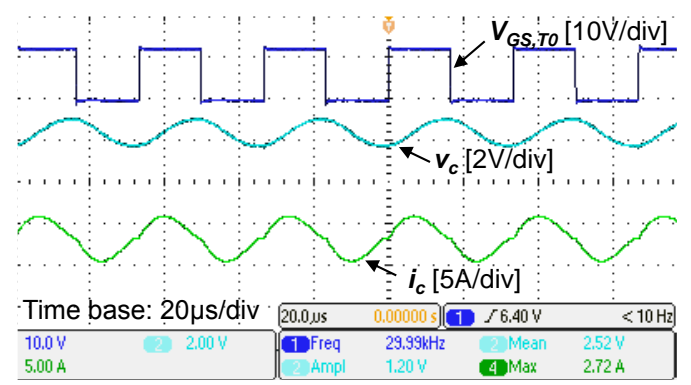

(a)

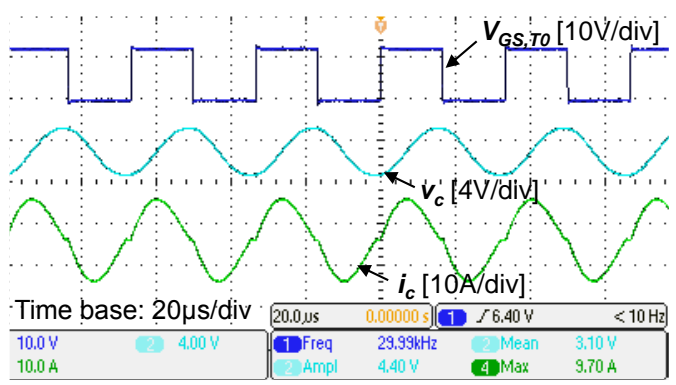

(b)

Figure 16. Measured voltage and current waveforms of the switch-capacitor and the gate-source voltage of $T_{0}$. (a) With an input source voltage of $3.4 \mathrm{~V}$; (b) with an input source voltage of $5 \mathrm{~V}$.

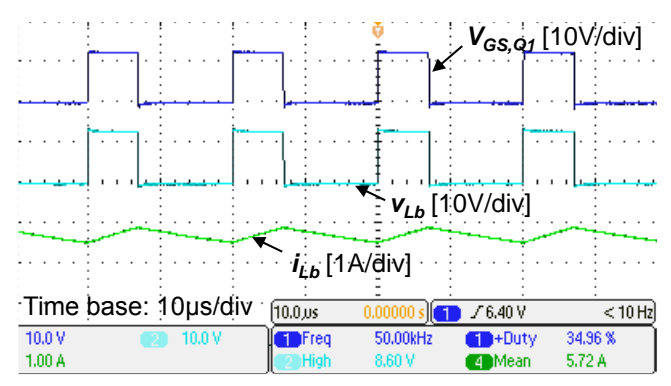

Figure 17. Voltage and current waveform of the power inductor, $L_{b}$. 


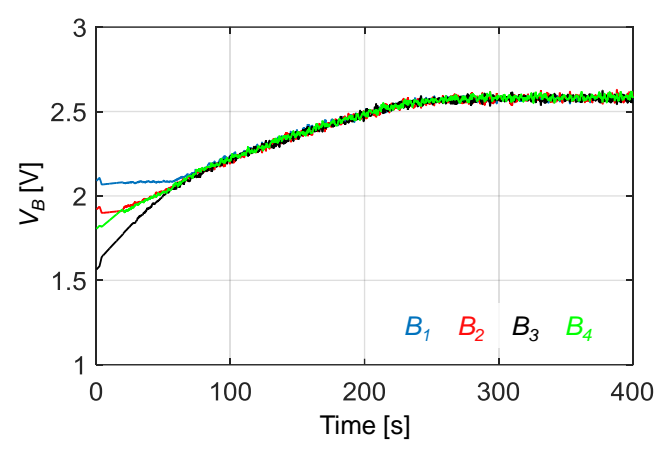

Figure 18. Measured EDLC cell voltage, charged by the CC-CV charger with the string-to-cells balancer.

Both the simulation and experimental results showed that with the presence of a BMS, which sensed the cell parameters and respectively controlled the SC current, the balancing speed could be dramatically increased with the multi-port SC converter. The behavior of the SC converter could be accurately described by the equivalent resistance. ZCS operation can be achieved by selecting the circuit parameters following Equations (3) and (5). With an additional step-up or step-down DC-DC converter, the external voltage source could be eliminated by implementing the controllable voltage source with the energy storage string.

\section{Conclusions}

This paper presents an alternative implementation of a multi-port ZCS SC converter, allowing an adjustable current for battery or super-capacitor management applications. In addition to the auto-balancing feature offered by the SC technique with simple complementary gating signals, the balancing speed can be dramatically increased by closed-loop control cooperating with the BMS and an adjustable voltage source. The SIMO SC converter allows separated control of the current charging to the cells whereas the MISO SC converter permits separated control current discharging from the cells. Furthermore, the configurations of string-to-cells and cells-to-string, as well as cells-to-cells equalizers, are proposed by an additional buck-boost converter or boost converter stage. Similar to the conventional SC converters, the charging or discharging current of the cell is determined by the equivalent resistance of the $\mathrm{SC}$ unit and the voltage difference between the cell and the voltage source. The equalizing speed can be increased by raising the source voltage for the SIMO SC converter and vice versa for the MISO SC converter. In the simulation setup, the balancing speed was increased by about ten times with the closed-loop control; whereas this was approximately seven times faster comparing to the traditional SC auto-balancing operation in the experimental measurement. However, increasing the balancing current by raising the voltage difference implies a sacrifice in energy efficiency. Considering the forward voltage drop of the diodes, the proposed multi-port SC converter would be more efficient with energy storage modules or ESS with a higher cell voltage.

Author Contributions: Y.C.F. developed the analysis and modeling of the converter. He also conducted the prototype testing and simulation. K.W.E.C. was responsible for the background theory of power converters and charge balancing. He also provided the guidance and supervision of the study. S.R.R. and X.W. provided useful suggestions on the study and the content of the paper.

Funding: This research received no external funding.

Acknowledgments: The authors wish to acknowledge the support provided by the members of the Power Electronics Research Centre (PERC) and Research Committee at the Hong Kong Polytechnic University.

Conflicts of Interest: The authors declare no conflict of interest. 


\section{References}

1. Hung, S.T.; Hopkins, D.C.; Mosling, C.R. Extension of Battery Life Via Charge Equalization Control. IEEE Trans. Ind. Electron. 1993, 40, 96-104. [CrossRef]

2. Cheng, K.W.E.; Divakar, B.P.; Wu, H.; Ding, K.; Ho, H.F. Battery-Management System (Bms) and Soc Development for Electrical Vehicles. IEEE Trans. Veh. Technol. 2011, 60, 76-88. [CrossRef]

3. Frost, D.F.; Howey, D.A. Completely Decentralized Active Balancing Battery Management System. IEEE Trans. Power Electron. 2018, 33, 729-738. [CrossRef]

4. Velho, R.; Beirão, M.; Calado, M.; Pombo, J.; Fermeiro, J.; Mariano, S. Management System for Large Li-Ion Battery Packs with a New Adaptive Multistage Charging Method. Energies 2017, 10, 605. [CrossRef]

5. Chatzakis, J.; Kalaitzakis, K.; Voulgaris, N.C.; Manias, S.N. Designing a New Generalized Battery Management System. IEEE Trans. Ind. Electron. 2003, 50, 990-999. [CrossRef]

6. Raman, S.R.; Xue, X.D.; Cheng, K.W.E. Review of Charge Equalization Schemes for Li-Ion Battery and Super-Capacitor Energy Storage Systems. In Proceedings of the 2014 International Conference on Advances in Electronics Computers and Communications, Bangalore, India, 10-11 October 2014.

7. Hurley, W.G.; Wong, Y.S.; Wolfle, W.H. Self-Equalization of Cell Voltages to Prolong the Life of Vrla Batteries in Standby Applications. IEEE Trans. Ind. Electron. 2009, 56, 2115-2120. [CrossRef]

8. Moo, C.S.; Hsieh, Y.C.; Tsai, I.S. Charge Equalization for Series-Connected Batteries. IEEE Trans. Aerosp. Electron. Syst. 2003, 39, 704-710. [CrossRef]

9. Kutkut, N.H.; Wiegman, H.L.N.; Divan, D.M.; Novotny, D.W. Design Considerations for Charge Equalization of an Electric Vehicle Battery System. IEEE Trans. Ind. Appl. 1999, 35, 28-35. [CrossRef]

10. Mestrallet, F.; Kerachev, L.; Crebier, J.C.; Collet, A. Multiphase Interleaved Converter for Lithium Battery Active Balancing. IEEE Trans. Power Electron. 2014, 29, 2874-2881. [CrossRef]

11. Wang, X.; Cheng, K.; Fong, Y. Non-Equal Voltage Cell Balancing for Battery and Super-Capacitor Source Package Management System Using Tapped Inductor Techniques. Energies 2018, 11, 1037. [CrossRef]

12. Pascual, C.; Krein, P.T. Switched Capacitor System for Automatic Series Battery Equalization. In Proceedings of the APEC 97-Applied Power Electronics Conference, Atlanta, GA, USA, 23-27 February 1997.

13. Xu, J.; Li, S.; Mi, C.; Chen, Z.; Cao, B. Soc Based Battery Cell Balancing with a Novel Topology and Reduced Component Count. Energies 2013, 6, 2726-2740. [CrossRef]

14. Liu, X.; Sun, Y.; He, Y.; Zheng, X.; Zeng, G.; Zhang, J. Battery Equalization by Fly-Back Transformers with Inductance, Capacitance and Diode Absorbing Circuits. Energies 2017, 10, 1482. [CrossRef]

15. Park, S.H.; Park, K.B.; Kim, H.S.; Moon, G.W.; Youn, M.J. Single-Magnetic Cell-to-Cell Charge Equalization Converter with Reduced Number of Transformer Windings. IEEE Trans. Power Electron. 2012, 27, 2900-2911. [CrossRef]

16. Hsieh, Y.H.; Liang, T.J.; Chen, S.M.O.; Horng, W.Y.; Chung, Y.Y. A Novel High-Efficiency Compact-Size Low-Cost Balancing Method for Series-Connected Battery Applications. IEEE Trans. Power Electron. 2013, 28, 5927-5939. [CrossRef]

17. Lim, C.S.; Lee, K.J.; Ku, N.J.; Hyun, D.S.; Kim, R.Y. A Modularized Equalization Method Based on Magnetizing Energy for a Series-Connected Lithium-Ion Battery String. IEEE Trans. Power Electron. 2014, 29, 1791-1799. [CrossRef]

18. Lee, K.M.; Lee, S.W.; Choi, Y.G.; Kang, B. Active Balancing of Li-Ion Battery Cells Using Transformer as Energy Carrier. IEEE Trans. Ind. Electron. 2017, 64, 1251-1257. [CrossRef]

19. Kim, C.H.; Kim, M.Y.; Moon, G.W. A Modularized Charge Equalizer Using a Battery Monitoring IC for Series-Connected Li-Ion Battery Strings in Electric Vehicles. IEEE Trans. Power Electron. 2013, 28, 3779-3787. [CrossRef]

20. Hannan, M.; Hoque, M.; Ker, P.; Begum, R.; Mohamed, A. Charge Equalization Controller Algorithm for Series-Connected Lithium-Ion Battery Storage Systems: Modeling and Applications. Energies 2017, 10, 1390. [CrossRef]

21. Imtiaz, A.M.; Khan, F.H. "Time Shared Flyback Converter" Based Regenerative Cell Balancing Technique for Series Connected Li-Ion Battery Strings. IEEE Trans. Power Electron. 2013, 28, 5960-5975. [CrossRef]

22. Xu, A.; Xie, S.; Liu, X. Dynamic Voltage Equalization for Series-Connected Ultracapacitors in EV/HEV Applications. IEEE Trans. Veh. Technol. 2009, 58, 3981-3987. 
23. Yuanmao, Y.; Cheng, K.W.E.; Yeung, Y.P.B. Zero-Current Switching Switched-Capacitor Zero-Voltage-Gap Automatic Equalization System for Series Battery String. IEEE Trans. Power Electron. 2012, 27, 3234-3242. [CrossRef]

24. Shang, Y.; Zhang, C.; Cui, N.; Guerrero, J.M. A Cell-to-Cell Battery Equalizer with Zero-Current Switching and Zero-Voltage Gap Based on Quasi-Resonant LC Converter and Boost Converter. IEEE Trans. Power Electron. 2015, 30, 3731-3747. [CrossRef]

25. Shang, Y.; Zhang, Q.; Cui, N.; Zhang, C. A Cell-to-Cell Equalizer Based on Three-Resonant-State Switched-Capacitor Converters for Series-Connected Battery Strings. Energies 2017, 10, 206. [CrossRef]

26. Shang, Y.; Lu, F.; Xia, B.; Zhang, C.; Cui, N.; Mi, C. A Switched-Coupling-Capacitor Equalizer for Series-Connected Battery Strings. In Proceedings of the 2017 IEEE Applied Power Electronics Conference and Exposition (APEC), Tampa, FL, USA, 26-30 March 2017.

27. Ye, Y.; Cheng, K. An Automatic Switched-Capacitor Cell Balancing Circuit for Series-Connected Battery Strings. Energies 2016, 9, 138. [CrossRef]

28. Ye, Y.; Cheng, K.W.E. Modeling and Analysis of Series-Parallel Switched-Capacitor Voltage Equalizer for Battery/Supercapacitor Strings. IEEE J. Emerg. Sel. Top. Power Electron. 2015, 3, 977-983. [CrossRef]

29. Kim, M.Y.; Kim, C.H.; Kim, J.H.; Moon, G.W. A Chain Structure of Switched Capacitor for Improved Cell Balancing Speed of Lithium-Ion Batteries. IEEE Trans. Ind. Electron. 2014, 61, 3989-3999. [CrossRef]

30. Ye, Y.; Cheng, K.W.E.; Fong, Y.C.; Xue, X.; Lin, J. Topology, Modeling, and Design of Switched-Capacitor-Based Cell Balancing Systems and Their Balancing Exploration. IEEE Trans. Power Electron. 2017, 32, 4444-4454. [CrossRef]

31. Altaf, F.; Egardt, B. Comparative Analysis of Unipolar and Bipolar Control of Modular Battery for Thermal and State-of-Charge Balancing. IEEE Trans. Veh. Technol. 2017, 66, 2927-2941. [CrossRef]

32. Ouyang, Q.; Chen, J.; Zheng, J.; Fang, H. Optimal Cell-to-Cell Balancing Topology Design for Serially Connected Lithium-Ion Battery Packs. IEEE Trans. Sustain. Energy 2018, 9, 350-360. [CrossRef]

33. Preindl, M. A Battery Balancing Auxiliary Power Module with Predictive Control for Electrified Transportation. IEEE Trans. Ind. Electron. 2018, 65, 6552-6559. [CrossRef]

34. Abdel-Monem, M.; Hegazy, O.; Omar, N.; Trad, K.; de Breucker, S.; van den Bossche, P.; van Mierlo, J. Design and Analysis of Generic Energy Management Strategy for Controlling Second-Life Battery Systems in Stationary Applications. Energies 2016, 9, 889. [CrossRef]

35. Mukherjee, N.; Strickland, D. Control of Second-Life Hybrid Battery Energy Storage System Based on Modular Boost-Multilevel Buck Converter. IEEE Trans. Ind. Electron. 2015, 62, 1034-1046. [CrossRef]

36. Shousha, M.; McRae, T.; Prodić, A.; Marten, V.; Milios, J. Design and Implementation of High Power Density Assisting Step-up Converter with Integrated Battery Balancing Feature. IEEE J. Emerg. Sel. Top. Power Electron. 2017, 5, 1068-1077. [CrossRef]

37. Fong, Y.C.; Cheng, K.W.E.; Ye, Y.; Chan, Y.C. Centralized Regulation Scheme for a Parallel-Mode Switched-Capacitor Converter System with Simple Unit Commitment. IEEE Trans. Ind. Electron. 2017, 64, 6149-6158. [CrossRef]

38. Ye, Y.; Cheng, K.W.E. Analysis and Optimization of Switched Capacitor Power Conversion Circuits with Parasitic Resistances and Inductances. IEEE Trans. Power Electron. 2017, 32, 2018-2028. [CrossRef]

39. Cheng, K.W.E.; Evans, P.D. Parallel-mode extended-period quasiresonant convertor. IEEE Proc. B 1991, 138, 243-251. [CrossRef]

40. Ye, Y.; Cheng, K.W.E.; Liu, J.; Xu, C. A Family of Dual-Phase-Combined Zero-Current Switching Switched-Capacitor Converters. IEEE Trans. Power Electron. 2014, 29, 4209-4218. [CrossRef]

41. Baughman, A.C.; Ferdowsi, M. Double-Tiered Switched-Capacitor Battery Charge Equalization Technique. IEEE Trans. Ind. Electron. 2008, 55, 2277-2285. [CrossRef]

42. Saxena, S.; Raman, S.R.; Saritha, B.; John, V. A Novel Approach for Electrical Circuit Modeling of Li-Ion Battery for Predicting the Steady-State and Dynamic I-V Characteristics. Sādhanā 2016, 41, 479-487.

43. Li, S.; Cheng, K.W.E.; Ye, Y.; Shi, Z. Wide Input and Wide Output Topology Analysis for Tapped-Inductor Converters with Consideration of Parasitic Elements. IET Power Electron. 2016, 9, 1952-1961. [CrossRef] 